\title{
Digestible methionine + cysteine: lysine ratios for growing meat-type quails
}

\author{
Mariana Resende de Castro ${ }^{1}$ Sandra Regina Freitas Pinheiro ${ }^{* *}$ Jéssica Amaral Miranda ${ }^{1}$ \\ Leonardo da Silva Costa $^{1} \odot$ Graziela Maria de Freitas Rocha ${ }^{1}$ \\ Renata Gomes de Oliveira $^{3}$ Paulo Gustavo Macedo de Almeida Martins ${ }^{2}$
}

${ }^{1}$ Departamento de Zootecnia, Universidade Federal dos Vales do Jequitinhonha e Mucuri (UFVJM), Rodovia MGT 367, km 583, n 5000, Alto da Jacuba, 39100-000, Diamantina, MG, Brasil. E-mail: sandrafreitaspinheiro@gmail.com. *Corresponding author. ${ }^{2}$ Instituto Federal do Norte de Minas Gerais (IFNMG), Almenara, MG, Brasil.

${ }^{3}$ Universidade Federal de Minas Gerais (UFMG), Belo Horizonte, MG, Brasil.

ABSTRACT: The objective was to estimate the most appropriate digestible methionine + cysteine:lysine ratios for growing meat-type quails (Coturnix coturnix) from 1 to 21 days of age. Quails were fed with a basal ration deficient in digestible methionine + cysteine, with five levels of DL-methionine, in substitution of glutamic acid and starch, resulting in digestible methionine + cysteine:lysine ratios of 0.61, 0.66, 0.71, 0.76 and 0.81. Feed and methionine + cysteine intake, body weight gain, feed conversion and uniformity were assessed. From 1 to 7 days, an increasing linear effect was observed for feed and methionine + cysteine intake, body weight gain, and uniformity, and a linear decrease for feed conversion. From 8 to 14 days, the 0.70 methionine + cysteine: lysine ratio was the best for feed intake and body weight gain, and for uniformity, the 0.75 methionine + cysteine:lysine ratio was the most appropriate. For methionine + cysteine intake and feed conversion, an increasing and decreasing linear adjustment was observed, respectively. From 15 to 21 days, an increasing linear effect was observed for feed and methionine + cysteine intake and body weight gain; a decreasing linear effect was observed for feed conversion. The 0.81 ratio was the most efficient for feed conversion during all evaluated experimental periods. In conclusion, the 0.81 dietary methionine + cysteine:lysine ratio is the most appropriate for meat-type quails during the first 21 days of age.

Key words: Coturnix coturnix, ideal protein, performance, sulfur amino acids.

Relações de metionina + cisteína: lisina digestíveis para codornas de corte em crescimento

RESUMO: $O$ objetivo foi estimar as relações metionina + cisteina: lisina digestiveis mais apropriadas para a criação de codornas de corte (Coturnix coturnix) de 1 a 21 dias de idade. As codornas foram alimentadas com uma ração basal deficiente em metionina + cisteína digestivel, com cinco níveis de DL-metionina, em substituição ao ácido glutâmico e ao amido, resultando nas relações metionina + cisteína: lisina digestiveis de 0,61;0,66;0,71; 0,76 e 0,81. O consumo de ração, a ingestão de metionina + cisteína, o ganho de peso corporal, a conversão alimentar e a uniformidade foram avaliados. De 1 a 7 dias, um efeito linear crescente foi observado para consumo de ração e de metionina + cisteína, ganho de peso corporal e uniformidade, e redução linear para conversão alimentar. De 8 a 14 dias, a relação metionina + cisteina: lisina de 0,70 foi melhor para consumo de ração e ganho de peso corporal, e para uniformidade, a relação metionina + cisteína: lisina de 0,75 foi a mais apropriada. Para consumo de metionina + cisteína e conversão alimentar, um ajuste linear crescente e decrescente foi observado, respectivamente. De 15 a 21 dias, um efeito linear crescente foi observado para consumo de ração e de metionina + cisteina e ganho de peso corporal; um efeito linear decrescente foi observado para conversão alimentar. A relação de 0,81 foi mais eficiente para a conversão alimentar durante todos os periodos experimentais avaliados. Conclui-se que a relação metionina + cisteína: lisina de 0,81 é mais apropriada para codornas de corte durante os primeiros 21 dias de idade.

Palavras-chave: aminoácidos sulfurosos, Coturnix coturnix, desempenho, proteína ideal.

\section{INTRODUCTION}

Protein and, or amino acids should be provided in adequate proportions during the initial growing phase for quails to express the greatest body development, with muscle mass formation, and better feathering (COSTA et al., 2013). However, the efficiency of dietary protein utilization is low leading to an increased nitrogen excretion throughout the feces (TON et al., 2013). This situation can be avoided by providing diets with the required digestible amino acid amounts.

Methionine is the first limiting amino acid in diets formulated for birds primarily with corn and soybean meal (LEESON \& SUMMERS, 2008). This nutrient, which is important for maintenance, growth, and feathering, is the precursor of cysteine in an irreversible process, with a special role in stabilizing the structure of many proteins by disulfide bonds (TESSERAUD et al., 2009). 
Recently, the Brazilian market is interested in meat-type quails but research on the nutritional requirements of these birds, determined at different growth stages, is limited (TEIXEIRA et al., 2013), and the knowledge of the ideal ratio of essential amino acids with lysine is low. Therefore, the objective was to estimate the most appropriate digestible methionine + cysteine: lysine ratios in diets for growing meat-type quails during the initial growing phase.

\section{MATERIALS AND METHODS}

Three experimental periods were carried out in the Aviculture Sector facilities of the Universidade Federal dos Vales do Jequitinhonha e Mucuri (UFVJM), in Diamantina, Minas Gerais State, Brazil (43⒊'W and $\left.18^{\circ} 12^{\prime} \mathrm{S}\right)$. Animals utilized in this experiment were cared for by acceptable practices, and the research protocol was reviewed and approved by the UFVJM, Committee of Ethics on the Use of Animals (approval number 032/2012).

A total of 1,440 different quails were utilized during three experimental periods. Birds were housed in 40 cages $\left(240,450\right.$ and $277 \mathrm{~cm}^{2} /$ bird for experimental period 1, 2 and 3, respectively). Each cage was equipped with a cup-pressure-type water trough and a gutter-type feeder, positioned in front of the cage. Incandescent light bulbs $(100,60$ or $40 \mathrm{~W})$ were available to provide artificial heating, which was monitored once a day $(0800 \mathrm{~h})$ to ensure thermal comfort. During the first experimental period, the average temperature values were $35.2 \pm 1.57^{\circ} \mathrm{C}$ and $38.8 \pm 0.77{ }^{\circ} \mathrm{C}$ for minimum and maximum, respectively. From 8 to 14 days and from 15 to 21 days, the average maximum and minimum temperatures values were $30.4 \pm 2.84{ }^{\circ} \mathrm{C}$ and $37.0 \pm 1.53{ }^{\circ} \mathrm{C}$, and $26.6 \pm 2.6$ and $35.2 \pm 1.53{ }^{\circ} \mathrm{C}$, respectively.

During the experimental period 1, 600 quails of both sexes were evaluated from day 1 to 7 , whereas in the experimental period 2, 320 quails of both sexes were evaluated from day 8 to 14 , and in the experimental period 3, 520 quails of both sexes were evaluated from day 15 to 21 . Quails utilized in each period were different individuals. Initial body weight was measured at the beginning of each experiment $(9.5 \pm 0.46,37.9 \pm 1.82$, and $87.4 \pm 2.07 \mathrm{~g}$, respectively), and quails were distributed in a completely randomized design, with 5 treatments, 8 replicates, and 15, 8 and 13 quails per experimental unit, in experiment 1, 2 and 3, respectively.

Quails were fed with a basal diet containing corn, soybean and corn gluten meal; this basal diet had $0.76 \%$ digestible methionine + cysteine, corresponding to the dietary methionine + cysteine: lysine ratio of 0.61 (control; Table 1). From this diet, four levels of DL- methionine were included, in substitution of glutamic acid and starch, corresponding to $0.66,0.71,0.76$ and 0.81 , in addition to the 0.61 dietary methionine + cysteine:lysine ratio. All evaluated diets were isoproteic and isoenergetic. Diets were formulated based on the digestible amino acid content of feedstuffs, as described by ROSTAGNO et al. (2011), according to nutritional requirements reported by SILVA \& COSTA (2009). For lysine, a sub-optimal level was utilized, corresponding to $10 \%$ reduction of the recommended level. All amino acid and lysine ratios, as proposed by SILVA \& COSTA (2009), were kept, except for methionine + cysteine. To assure no deficiencies, an inclusion of 3\% more of the requirements of each amino acid was added, except for lysine and methionine + cysteine. When quails were not in the experimental period, they were fed with the basal diet.

Feed (FI) and methionine + cysteine intake (MCI), body weight gain (BWG), feed conversion (FC), and uniformity (UNIF) were assessed in all experiment periods. Feed intake per quail was corrected by the date of death, when occurred. For uniformity, a $10 \%$ variation of the average batch body weight was considered.

The evaluated variables were subjected to ANOVA, according to models of simple or quadratic polynomial regression, utilizing the REG procedures of SAS (SAS Institute Inc., Cary, NC, USA), and Linear Response Plateau (LRP), utilizing the NLIN procedures of SAS. When the simultaneous adjustment of models was possible, the estimate of the best ratio value was obtained by the first intersection of the quadratic equation with the LRP, as described by SAKOMURA \& ROSTAGNO (2007).

\section{RESULTS AND DISCUSSION}

\section{Experimental period 1}

During this period, the increasing dietary methionine + cysteine: lysine ratio resulted in a linear increase $(\mathrm{P}<0.01)$ of feed intake $(\mathrm{FI}=16.572+25.07 \mathrm{X}$; $\mathrm{R}^{2}=0.88$; Table 2). Deficiency of methionine in the diet is crucial in controlling feed intake because diets with inadequate levels can increase or decrease intake. SUMMERS \& LEESON (1985) reported that birds tend to increase when provided with diets slightly deficient. Nonetheless, these authors also reported that severe deficiencies reduce intake, thus, the degree of methionine deficiency in the diet will determine the reduction or increase in feed intake. Similarly, FERREIRA et al. (2012a) observed an effect on feed intake, when evaluating total methionine + cysteine levels (from 0.73 to $1.03 \%$ ), for meat-type quails during first week of life, being the 0.94 level estimate for this trait, correspond to the dietary methionine + cysteine:lysine ratio of 0.72 . Dietary methionine + 
Table 1 - Nutrient composition of diets provided to meat-type quails (Coturnix coturnix) from 1 to $21 \mathrm{~d}$ of age (Experiments 1,2 and 3 ).

\begin{tabular}{|c|c|c|c|c|c|}
\hline \multirow{2}{*}{ Ingredients, $\%$} & \multicolumn{5}{|c|}{ 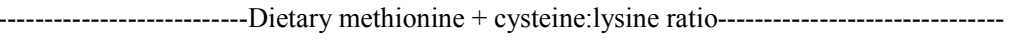 } \\
\hline & 0.61 & 0.66 & 0.71 & 0.76 & 0.81 \\
\hline Corn meal & 50.97 & 50.97 & 50.97 & 50.97 & 50.97 \\
\hline Soybean meal & 34.11 & 34.11 & 34.11 & 34.11 & 34.11 \\
\hline Corn gluten meal & 10.0 & 10.0 & 10.0 & 10.0 & 10.0 \\
\hline Limestone & 1.22 & 1.22 & 1.22 & 1.22 & 1.22 \\
\hline Dicalcium phosphate & 1.16 & 1.16 & 1.16 & 1.16 & 1.16 \\
\hline White-stock salt & 0.38 & 0.38 & 0.38 & 0.38 & 0.38 \\
\hline Mineral premix ${ }^{1}$ & 0.20 & 0.20 & 0.20 & 0.20 & 0.20 \\
\hline Vitamin premix ${ }^{2}$ & 0.20 & 0.20 & 0.20 & 0.20 & 0.20 \\
\hline Choline chloride $(60 \%)$ & 0.01 & 0.01 & 0.01 & 0.01 & 0.01 \\
\hline L-Lysine $\mathrm{HCl}(78 \%)$ & 0.23 & 0.23 & 0.23 & 0.23 & 0.23 \\
\hline DL-Methionine (99\%) & 0.00 & 0.07 & 0.13 & 0.19 & 0.25 \\
\hline L-Threonine (98\%) & 0.12 & 0.12 & 0.12 & 0.12 & 0.12 \\
\hline L-Isoleucine (98\%) & 0.06 & 0.06 & 0.06 & 0.06 & 0.06 \\
\hline L-Arginine (99\%) & 0.34 & 0.34 & 0.34 & 0.34 & 0.34 \\
\hline L-Glutamic (95\%) & 0.50 & 0.43 & 0.36 & 0.31 & 0.24 \\
\hline Starch & 0.50 & 0.50 & 0.51 & 0.50 & 0.51 \\
\hline Total & 100.0 & 100.0 & 100.0 & 100.0 & 100.0 \\
\hline \multicolumn{6}{|c|}{ 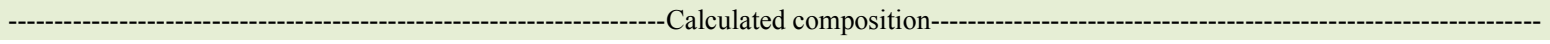 } \\
\hline Metabolized energy, $\mathrm{kcal} / \mathrm{kg}$ & 2900 & 2900 & 2900 & 2900 & 2900 \\
\hline Crude protein, $\%$ & 26.12 & 26.12 & 26.12 & 26.12 & 26.12 \\
\hline Calcium, \% & 0.85 & 0.85 & 0.85 & 0.85 & 0.85 \\
\hline Available phosphorus, $\%$ & 0.32 & 0.32 & 0.32 & 0.32 & 0.32 \\
\hline Sodium, \% & 0.17 & 0.17 & 0.17 & 0.17 & 0.17 \\
\hline Crude fiber, $\%$ & 2.72 & 2.72 & 2.72 & 2.72 & 2.72 \\
\hline \multicolumn{6}{|c|}{ 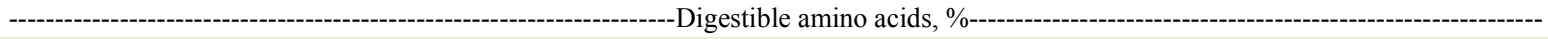 } \\
\hline Lysine & 1.25 & 1.25 & 1.25 & 1.25 & 1.25 \\
\hline Methionine + Cysteine & 0.76 & 0.83 & 0.89 & 0.95 & 1.01 \\
\hline Tryptophan & 0.21 & 0.21 & 0.21 & 0.21 & 0.21 \\
\hline Threonine & 0.98 & 0.98 & 0.98 & 0.98 & 0.98 \\
\hline Arginine & 1.79 & 1.79 & 1.79 & 1.79 & 1.79 \\
\hline Isoleucine & 1.07 & 1.07 & 1.07 & 1.07 & 1.07 \\
\hline Valine & 1.10 & 1.10 & 1.10 & 1.10 & 1.10 \\
\hline
\end{tabular}

${ }^{1}$ Composition: Manganese: $160 \mathrm{~g} / \mathrm{kg}$; Iron: $100 \mathrm{~g} / \mathrm{kg}$; Zinc: $100 \mathrm{~g} / \mathrm{kg}$, Copper: $20 \mathrm{~g} / \mathrm{kg}$; Cobalt: $2 \mathrm{~g} / \mathrm{kg}$; and Iodine: $2 \mathrm{~g} / \mathrm{kg}$. ${ }^{2} \mathrm{Composition}$ : Vitamin A (retinyl acetate): 12.000.000IU $/ \mathrm{kg}$; Vitamin $\mathrm{D}_{3}$ : 3.600.000IU/kg; Vitamin E (dl- $\alpha$-tocopheryl acetate): 3.500IU/kg; Vitamin $\mathrm{B}_{1}$ : $2.500 \mathrm{mg} / \mathrm{kg}$; Vitamin $\mathrm{B}_{2}: 8.000 \mathrm{mg} / \mathrm{kg}$; Vitamin $\mathrm{B}_{6}: 5.000 \mathrm{mg} / \mathrm{kg} ;$ Pantothenic acid: $12.000 \mathrm{mg} / \mathrm{kg} ;$ Biotin: 200mg/kg; Vitamin K: 3.000mg/kg; Folic acid: $1.500 \mathrm{mg} / \mathrm{kg}$; Niacin: $40.000 \mathrm{mg} / \mathrm{kg}$; Vitamin $\mathrm{B}_{12}: 20.000 \mathrm{mg} / \mathrm{g}$; and Selenium: $150 \mathrm{mg} / \mathrm{kg}$.

cysteine intake $\left(\mathrm{MCI}=-15.009+64.352 \mathrm{X} ; \mathrm{R}^{2}=0.98\right)$ had a linear increase $(\mathrm{P}<0.01)$ with increasing methionine + cysteine:lysine ratios in diets. This result may be attributed to the synthetic methionine supplementation and to the increase on feed intake.

There was an effect $(\mathrm{P}<0.01)$ for body weight gain as the dietary methionine + cysteine:lysine ratio increased, based on linear $(\mathrm{BWG}=-3.046+39.577 \mathrm{X}$; $\left.\mathrm{R}^{2}=0.85\right)$, quadratic $\left(\mathrm{BWG}=-99.642+314.404 \mathrm{X}-193.54 \mathrm{X}^{2}\right.$; $\mathrm{R}^{2}=0.92$ ), and LRP adjustments $[\mathrm{BWG}=27.575-61.798$
$\left.(0.728-\mathrm{X}) ; \mathrm{R}^{2}=0.87\right]$. This result can be explained by the increase in feed intake and because methionine is essential for growth, maintenance and feather development (PINTO et al., 2003). The estimate for the best dietary methionine + cysteine:lysine ratio obtained by the quadratic model was 0.79 , and by the LRP, 0.73 . However, the 0.76 methionine + cysteine:lysine ratio is obtained by the first intersection of the quadratic equation with a plateau of the LRP for greater BWG of meat-type quails from 1 to 7 days of age. Methionine is an important sulfur amino 
Table 2 - Performance of meat-type quails (Coturnix coturnix) fed increasing digestible methionine + cysteine:lysine ratios from 1 to 21 days of age.

\begin{tabular}{|c|c|c|c|c|c|c|c|}
\hline \multirow{2}{*}{ Item } & \multicolumn{5}{|c|}{------Dietary methionine + cysteine: lysine ratio--------- } & \multirow{2}{*}{$\mathrm{SEM}^{1}$} & \multirow{2}{*}{$P$-value } \\
\hline & 0.61 & 0.66 & 0.71 & 0.76 & 0.81 & & \\
\hline \multicolumn{8}{|l|}{--------------------------- } \\
\hline Feed intake, g/quail & 30.98 & 34.14 & 34.45 & 35.45 & 36.59 & 3.981 & 0.0003 \\
\hline Methionine + cysteine intake, $\mathrm{mg}$ /quail & 23.55 & 28.34 & 30.87 & 33.66 & 36.96 & 2.135 & 0.0003 \\
\hline Body weight gain, g/quail & 19.47 & 24.98 & 25.65 & 26.57 & 28.57 & 1.352 & 0.0001 \\
\hline Feed conversion, g/g & 1.59 & 1.36 & 1.35 & 1.33 & 1.28 & 0.194 & 0.0002 \\
\hline Uniformity, \% & 45.58 & 56.95 & 57.27 & 59.76 & 64.00 & 13.871 & 0.0174 \\
\hline \multicolumn{8}{|c|}{ - } \\
\hline Feed intake, g/quail & 86.46 & 90.09 & 93.68 & 91.50 & 91.94 & 4.613 & 0.0017 \\
\hline Methionine + cysteine intake, mg/quail & 67.62 & 74.77 & 83.38 & 86.93 & 92.38 & 5.129 & 0.0001 \\
\hline Body weight gain, g/quail & 44.27 & 49.74 & 51.43 & 53.27 & 53.18 & 3.665 & 0.0001 \\
\hline Feed conversion, $\mathrm{g} / \mathrm{g}$ & 1.96 & 1.82 & 1.83 & 1.72 & 1.73 & 0.091 & 0.0001 \\
\hline Uniformity, \% & 54.69 & 81.25 & 67.19 & 65.63 & 50.88 & 28.266 & 0.0447 \\
\hline \multicolumn{8}{|c|}{ 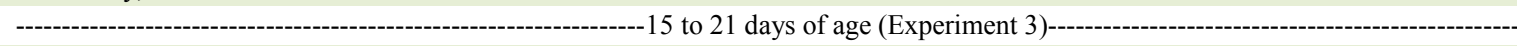 } \\
\hline Feed intake, g/quail & 134.08 & 137.25 & 141.06 & 143.35 & 141.15 & 7.606 & 0.0067 \\
\hline Methionine + cysteine intake, $\mathrm{mg} /$ quail & 101.90 & 113.92 & 125.55 & 136.19 & 142.57 & 8.335 & 0.0014 \\
\hline Body weight gain, g/quail & 61.24 & 64.99 & 66.83 & 69.43 & 70.11 & 4.567 & 0.0001 \\
\hline Feed conversion, g/g & 2.19 & 2.11 & 2.11 & 2.06 & 2.01 & 0.109 & 0.0001 \\
\hline Uniformity, \% & 70.22 & 70.27 & 66.82 & 75.42 & 78.68 & 15.289 & 0.1150 \\
\hline
\end{tabular}

${ }^{1}$ Standard error of the mean

acid in the translation of messenger RNA, being the first amino acid incorporated in the N-terminal position of all proteins (LIMA et al., 2015). According to these authors, methionine requirement for maintenance and synthesis of feather proteins is as important as the requirement for body protein synthesis. The improvement of average daily intake of methionine + cysteine from 3.36 to $5.28 \mathrm{mg} /$ quail provided an increment in BWG from 2.79 to $4.08 \mathrm{~g} /$ quail, for the dietary methionine + cysteine: lysine ratio of 0.61 and 0.81 , respectively, which correspond to approximately $32 \%$ increase. However, FERREIRA et al. (2012a) reported that $0.95 \%$ level of methionine + cysteine had the greatest BWG for quails, which correspond to the dietary methionine + cysteine: lysine ratio of 0.73 . This ratio is lesser than the ratio (0.81) evaluated in the present study.

As the dietary methionine + cysteine: lysine ratio increased, the feed conversion value decreased $(\mathrm{P}<0.01)$, according to the regression equation: $\mathrm{FC}=2.336-1.336 \mathrm{X} ; \mathrm{R}^{2}=0.74$. There was an improved supply of amino acids containing higher methionine + cysteine: lysine ratios, resulting in great synthesis of body protein and, consequently, increased BWG and a decrease in the feed conversion value. Conversely, LIMA et al. (2011), when evaluating increasing dietary methionine + cysteine: lysine ratios in diets provided to Japanese quails during the first week of age, reported that a lower ratio $(0.75)$ resulted in the more appropriate feed conversion. Nonetheless, FERREIRA et al. (2012b) reported improvement on feed conversion of meattype quails at 21 days of age, until $0.96 \%$ methionine + cysteine. SILVA et al. (2012) mentioned that heavier quails require more amino acids in comparison with Japanese quail, probably because of the increased growth rate and body weight.

A linear $(\mathrm{P}<0.01)$ effect was obtained for uniformity $\left(\mathrm{UNIF}=8.40+68.049 \mathrm{X} ; \mathrm{R}^{2}=0.62\right.$ ). The greatest dietary methionine + cysteine: lysine ratio resulted in an increased growth and development of quails, so those with great body weight had less amplitude, thus providing greater uniformity. According to LEESON \& SUMMERS (2008), quails during the first phase, even not producing an adult complex of digestive enzymes, can utilize the complex substrates present in a corn- and soybean-based diet; so, when a balanced diet is provided, the growth rate is maximized. While the growth rate is critical to the performance of a batch, uniformity has become a constant concern, because once there is a non-uniform batch, performance will be hampered until slaughter. 


\section{Experimental period 2}

A quadratic effect of methionine + cysteine: lysine ratio was observed $(\mathrm{P}<0.01)$ on feed intake until 0.74 , estimated by the regression equation: $\mathrm{FI}=-113.788+558.545 \mathrm{X}-377.429 \mathrm{X}^{2} \quad\left(\mathrm{R}^{2}=0.89\right.$; Table 2). According to the discontinuous model $[\mathrm{FI}=92.25$ $\left.72.429(0.689-\mathrm{X}) ; \mathrm{R}^{2}=0.96\right]$, the greatest feed intake was observed for the 0.69 ratio, whereas by the intersection of the quadratic equation with the LRP, it was observed that the 0.70 dietary methionine + cysteine: lysine ratio had the greatest feed intake. The 0.76 and 0.81 dietary ratios probably had an excess of sulfur amino acids, thereby quails decreased feed intake, in this ratios, to keep the balance of methionine + cysteine consumed. Notwithstanding, SCHERER (2009) reported an effect of methionine + cysteine: lysine ratio on BWG of European quails at 14 days of age, being the 0.78 ratio what affected this trait. Considering the crude protein level $(26 \%)$ in the present study and according to ROSTAGNO et al. (2006), the requirements of essential and non-essential amino acids possibly increase according to the high crude protein levels in the diet, suggesting that this discordance can be attributed to the differences in crude protein levels of these experiments. LIMA et al. (2015) reported that the high amino acid ratio $(0.78)$ provided an increased feed intake in Japanese quail. Considering that feed intake of Japanese quails is lesser than European quails, the former birds are more exigent in sulfurous amino acids to supply their requirements. An increasing linear effect $(\mathrm{P}<0.01)$ was observed for methionine + cysteine intake $(\mathrm{MCI}=-6.92+123.891 \mathrm{X}$; $\mathrm{R}^{2}=0.89$ ), attributed to an increase in feed intake and synthetic methionine supplementation to obtain the target methionine + cysteine: lysine ratios.

The BWG was also affected $(\mathrm{P}<0.01)$ by treatments (methionine + cysteine:lysine ratio) until 0.78 , estimated by the quadratic regression equation: $\quad \mathrm{BWG}=-135.169+484.518 \mathrm{X}-311.245 \mathrm{X}^{2}$ $\left(\mathrm{R}^{2}=0.98\right)$, and until 0.73 , according to the LRP model $\left[\mathrm{BWG}=53.224-70.718(0.726-\mathrm{X}) ; \mathrm{R}^{2}=0.82\right]$. By the intersection of the quadratic equation with the LRP, it was observed that the 0.75 ratio represented the greatest BWG. The findings reported by LIMA et al. (2015) corroborate the data from this study as they reported better weight gain with high $(0.78)$ dietary methionine + cysteine:lysine ratio of Japanese quail during the growing period.

The feed conversion value decreased $(\mathrm{P}<0.01)$ as the dietary methionine + cysteine: lysine ratio increased, according to the regression equation: $\mathrm{FC}=2.585-1.094 \mathrm{X} \quad\left(\mathrm{R}^{2}=0.82\right)$. The increase in $\mathrm{BWG}$, associated with a decrease in the feed conversion value, can be an indication that balanced feed increase the efficiency of utilization of nutrients to maximize growth.

The uniformity of quails was affected $(\mathrm{P}<0.05)$ as the dietary methionine + cysteine: lysine ratio increased until 0.70 , according to the equation: $\mathrm{UNIF}=-903,042+2798.571 \mathrm{X}-2003.571 \mathrm{X}^{2}\left(\mathrm{R}^{2}=0.71\right)$. Similarly, LIMA et al. (2015) reported a quadratic effect for uniformity for the methionine + cysteine: lysine ratio in the diet of Japanese quails at 40 days of age. These authors reported that the best ratio for uniformity was 0.73 .

\section{Experimental period 3}

Feed intake increased $(\mathrm{P}<0.01)$ according to the increasing dietary methionine + cysteine: lysine ratio, as estimated by the equation $\mathrm{FI}=111.157+39.803 \mathrm{X} \quad\left(\mathrm{R}^{2}=0.75\right) . \quad$ Nonetheless, the LRP model [FI=142.3-69.983(0.728-X); $\mathrm{R}^{2}=0.83$ ] better fitted to the result, estimating the ratio of 0.73 . As the diets were isoproteic and isoenergetic, and the greatest dietary methionine + cysteine: lysine ratios ( 0.76 to 0.81$)$ determined the plateau for feed intake, these greatest dietary ratios probably had an excess of sulfur amino acid. The methionine + cysteine intake linearly increased $(\mathrm{P}<0.01)$ according to the methionine + cysteine:lysine ratios $(\mathrm{MCI}=-22.493+206.42 \mathrm{X}$; $\mathrm{R}^{2}=0.97$ ) because of the increase of feed intake and amino acid (methionine) supplementation.

The increase in amino acid ratios resulted in improved $\mathrm{BWG}(\mathrm{P}<0.01), \mathrm{BWG}=35.376+43.903 \mathrm{X}$; $\mathrm{R}^{2}=0.95$. However, the LRP model $[\mathrm{BWG}=70.117$ $52.441(0.770-\mathrm{X}) ; \mathrm{R}^{2}=0.96$ ] better fitted to the results, with 0.77 being the most appropriate dietary methionine + cysteine:lysine ratio. This estimate is similar to the dietary methionine + cysteine:lysine ratio reported by SCHERER (2009), who reported 0.78 for meat-type quails from 1 to 14 days of age. However, the greatest BWG was estimated for quails fed $0.95 \%$ methionine + cysteine diet, being 0.73 methionine + cysteine: lysine ratio for European quail at 35 days of age (FERREIRA et al., 2012b).

The feed conversion value decreased $(\mathrm{P}<0.01)$ as the dietary methionine + cysteine: lysine ratio increased, according to the decreasing linear equation: $\mathrm{FC}=2.677-0.813 \mathrm{X}\left(\mathrm{R}^{2}=0.93\right)$. The increase of the average daily methionine + cysteine intake from $14.5 \mathrm{mg}$ /quail to $20.4 \mathrm{mg}$ /quail provided a decrease in the feed conversion value from 2.19 to 2.01 , for the dietary methionine + cysteine: lysine ratio of 0.61 and 0.81 , respectively. This reduction corresponded to an $8.2 \%$ improvement in efficiency of feed conversion during this period. Uniformity was not affected $(\mathrm{P}>0.05)$ by the increasing dietary methionine + cysteine: lysine ratio. 


\section{CONCLUSION}

In conclusion, the 0.81 dietary methionine + cysteine:lysine ratio is the most appropriate for meat-type quails during the first 21 days of age.

\section{ACKNOWLEDGMENTS}

The authors thank Fundação de Amparo à Pesquisa de Minas Gerais (FAPEMIG), for financial support (grant number APQ 01403-13), and Coordenação de Aperfeiçoamento de Pessoal de Nível Superior (CAPES), for a scholarship to Mariana Resende de Castro. In addition, the authors express appreciation to 'Ajinomoto do Brasil Indústria e Comércio de Alimentos Ltda.', for providing the amino acids, as well as to the Universidade Federal dos Vales do Jequitinhonha e Mucuri (UFVJM), Poultry Sector personnel, for the diligent animal care.

\section{BIOETHICS AND BIOSSECURITY COMMITTEE APPROVAL}

The research protocol was reviewed and approved by the Universidade Federal dos Vales do Jequitinhonha e Mucuri (UFVJM), Committee of Ethics on the Use of Animals (approval number 032/2012).

\section{DECLARATION OF CONFLICT OF INTEREST}

The authors declared no potential conflicts of interest with respect to the research, authorship, and/or publication of this article.

\section{REFERENCES}

COSTA, F.G.P. et al. Exigências nutricionais para codornas europeias. Lavras: Suprema Gráfica, 2013.134p.

FERREIRA, F. et al. Exigência de metionina + cistina para codornas de corte durante a fase de crescimento. Arquivo Brasileiro de Medicina Veterinária e Zootecnia, v.64, n.1, p.120-126, 2012a. Available from: $<$ http://www.scielo.br/pdf/abmvz/v64n1/a18v64n1.pdf>. Accessed: May. 20, 2013. doi: 10.1590/S0102-0935201200010001.

FERREIRA, F. et al.Teor de metionina + cistina total para codornas de corte do grupo genético EV2 durante o período de crescimento. Arquivo Brasileiro de Medicina Veterinária e Zootecnia, v.64, p.665-674, 2012b. Available from: <http://www.scielo.br/ scielo.php?script $=$ sci $\quad$ arttex\&pid $=S 0102-09352012000300019>$. Accessed: May. 20, 2013. doi: 10.1590/S0102-09352012000300019.

LEESON, S.; SUMMERS. J.D. Commercial poultry nutrition. 3.ed. Guelph, Canada: Nottingham University Press, 2008.

LIMA, H.J.D. et al. Relação entre metionina + cistina digestíveis e lisina digestível em dieta para codornas japonesas na fase pré-inicial. Enciclopédia Biosfera, v.7, p.926-931, 2011. Available from: $<$ http://www.conhecer.org.br/eniclop/2011b/ciencias\%20agrarias/ relacao\#20metionina.pdf>. Accessed: Jan. 12, 2017.
LIMA, H.J.D. et al. Ideal ratio of digestible methionine plus cystine to digestible lysine for growing Japanese quails. Revista Colombiana de Ciencias Pecuarias, v.28, p.313-322, 2015. Available from: $<$ http://www.scielo.org.co/pdf/rccp/v28n4/v28n4a04.pdf $>$. Accessed: Jan. 12, 2017. doi: 10.17533/udea.rccp.v28n4a03.

PINTO, R. et al. Exigência de metionina mais cisteína para codornas japonesas em crescimento. Revista Brasileira de Zootecnia, v.32, n.5, p.1174-1181, 2003. Available from: <http:// www.scielo.br/pdf/rbz/v32n5/17899.pdf>. Accessed: May. 20, 2013. doi: 10.1590/S1516-35982003000500017.

ROSTAGNO, H.S. et al. Recomendações aminoacídicas para frangos de corte. In: II Congresso Latino-Americano de Nutrição Animal, 2006, São Paulo, SP. Anais... São Paulo: CBNA, 2006, p.1-12.

ROSTAGNO, H.S. et al. Tabelas brasileiras para aves e suínos: composição de alimentos e exigências nutricionais. Viçosa: Editora UFV, 2011. 252 p.

SAKOMURA, N.K.; ROSTAGNO, H.S. Métodos de pesquisa em nutrição de monogástricos. Jaboticabal: FUNEP, 2007. p. 283.

SCHERER, C. Exigência de energia metabolizável, lisina e metionina+cisteína digestíveis para codornas de corte em fase de crescimento. 2009. 111p. Tese Doutorado em Zootecnia. Curso de Pós-graduação em Zootecnia, Universidade Estadual de Maringá.

SILVA, J.H.V.; COSTA, F.G.P. Tabelas para codornas japonesas e européias. Jaboticabal: FUNEP, 2009. p.107.

SILVA, J.H.V. et al. Exigências nutricionais de codornas. Revista Brasileira de Saúde Produção Animal, v.13, p.775-790, 2012. Available from: <http://www.scielo.br/scielo.php?script=sci_artte xt\&pid=S1519-99402012000300016>. Accessed: Nov. 06, 2017. doi: $10.1590 /$ S1519-99402012000300016.

SUMMERS, J.D.; LEESON, S. Broiler carcass composition as affected by amino acid supplementation. Canadian Journal of Animal Science, v.65, n.3, p.717-723, 1985. Available from: $<$ http://www.nrcresearchpress.com/doi/abs/10.4141/cjas85-084>. Accessed: Nov. 14, 2017. doi: 10.4141/cjas85-084.

TEIXEIRA, B.B. et al. Desempenho de codornas de corte submetidas a diferentes níveis de proteína bruta e energia metabolizável. Ciência Rural, v.43, n.3, p.524-529, 2013. Available from: $<$ http://www. scielo.br/scielo.php?pid=S0103-84782013000300025\&script $=$ sci abstract\&tlng=pt $>$. Accessed: Nov. 07, 2017. doi: 10.1590/S010384782013005000014 .

TESSERAUD, S. et al. Role of sulfur amino acids in controlling nutrient metabolism and cell functions: implications for nutrition. British Journal of Nutrition, v.101, p.1132-1139, 2009. Available from: <https://doi.org/10.1017/S0007114508159025>. Accessed: Dec. 12, 2012. doi: 10.1017/S0007114508159025.

TON, A.P.S. et al. Exigência de treonina digestível para codornas de corte no período de 15 a 35 dias de idade. Arquivo Brasileiro Medicina Veterinária Zootecnia, v.65, n.2, p.505-512, 2013. Available from: $<$ http://dx.doi.org/10.1590/S0102-09352013000200029>. Accessed: Nov. 14, 2017. doi: 10.1590/S0102-09352013000200029. 